Acta vet. scand. $1984,25,67-75$.

From the University of Troms $\varnothing$, Institute of Medical Biology and

Department of Arctic Biology, and National Veterinary Institute,

Oslo, Norway.

\title{
EFFECTS OF DIFFERENT DIETS ON VIABILITY, AND GUT MORPHOLOGY AND BACTERIOLOGY IN CAPTIVE WILLOW PTARMIGAN CHICKS (LAGOPUS L. LAGOPUS)
}

By

Ingolf Hanssen, Reinert Grammeltvedt and Anne-Lill Hellemann

HANSSEN, I., R. GRAMMELTVEDT and A.-L. HELLEMANN: Effects of different diets on viability, and gut morphology and bacteriology in captive willow ptarmigan chicks (Lagopus l. lagopus). Acta vet. scand. 1984, 25, 67-75. - Young willow ptarmigan chicks were fed an artificial chick diet (ACD), and different supplements. One group got ascorbic acid supplements, another neomycin and oxytetracyclin in the water, and a third was given ascorbic acid and sprouts of Vaccinium myrtillus. Chicks that were fed ACD only, showed low weight gain and high mortality rate. The numbers of bacteria in the gut were high and the incidence of villous epithelium erosion and bacteria colonizing the gut epithelium were high.

Admixture of ascorbic acid to the diet improved the viability of the chicks and reduced the number of coliforms in the gut.

Antibiotics in the water reduced the number of $\mathrm{C}$. perfringens, enterococci and coliforms in the gut, and improved the gut epithelium conditions.

Combined supplements of ascorbic acid and Vaccinium myrtillus resulted in strongly viable chicks with healthy gut epithelium. C. perfringens was not demonstrated in the gut, and the numbers of enterococci and coliforms were low.

willow ptarmigan; nutrition; gut morphology and bacteriology.

Young willow ptarmigan (Lagopus l. lagopus) chicks never survive longer than three weeks on commercial chicken feed. Enteritis is apparent 2-3 days after hatching, and is followed by retarded growth and osteochondrosis. Administration of megadoses ascorbic acid prevents the development of osteochondrosis and also reduce the frequency of enteritis significantly (Hanssen 
et al. 1979). A further reduction of enteritis frequency and improvement of chick growth is achieved if young shoots of blueberry plants (Vaccinium myrtillus), a natural ptarmigan chick feed item, are supplemented (Hanssen \& Ness 1982).

In the present work we have studied how supplements of ascorbic acid, blueberry sprouts and a mixture of neomycin and oxytetracyclin affect the viability and gut morphology and bacteriology of young willow piarmigan chicks.

\section{Chicks and rearing}

\section{MATERIALS AND METHODS}

Eggs from captive ptarmigan hens were incubated and hatched in machines (Hanssen et al. 1982). Twelve to 24 hours after hatching they were weighed and banded and divided randomly between four cages with ten chicks in each. The $1 \dot{m}^{2}$ cages had fine wire mesh floors, and were warmed by two $250 \mathrm{~W}$ infra-red lamps. Shelter was provided by plastic flowers, feed was placed in low feed trays, and water was provided in conventional chick water fountains. Feed was replenished and water fountains were washed once a day.

The composition and the analysis of the artificial chick diet (ACD) are presented in Table 1, while the supplements for the different groups are given in Table 2. Chicks that died during the experiment were autopsied.

\section{Bacteriological investigations of gut contents}

Seven days after hatching surviving chicks were weighed and killed. The chicks were immediately evicerated. The small intestine and caeca were opened, and the contents were aseptically secured, weighed and transferred to $100 \mathrm{ml}$ sterile $0.9 \%$ saline. From this mixture hundred-fold dilutions were transferred onto the surface of $5 \%$ human blood agar, bromthymolbluelactose agar (Nordic Committee on Food Analysis 1979) and typticase soy agar plates. All incubations were made at $37^{\circ} \mathrm{C}$. Parallels of blood agar plates were incubated for $24 \mathrm{~h}$ aerobically and five days anaerobically (Gas Pak System). The bromthymolbluelactose agar plates were incubated aerobically for $24 \mathrm{~h}$, while the trypticase soy agar plates were incubated anaerobically for five days (Gas Pak System). The isolated bacteria were classified into families, genera and species on the basis of cultural, morphological and biochemical properties (Bergey's Manual of De- 
T a ble 1. Composition and analysis of artificial chick diet (ACD).

\begin{tabular}{lc}
\hline Ingredients & \% fresh wt. \\
\hline Soya meal (extracted) & 10.0 \\
Herring meal & 10.0 \\
Maize & 25.0 \\
Wheat & 25.0 \\
Wheat bran & 17.1 \\
Brewer's yeast & 2.0 \\
Limestone & 1.5 \\
Calcium phosphate & 2.0 \\
Skimmed milk powder & 2.0 \\
Blood meal & 2.0 \\
Whey powder & 2.0 \\
Vitamin premix $\left(^{*}\right)$ & 1.0 \\
Trace mineral premix $\left(^{\star *}\right)$ & 0.4 \\
Analysis & $\%$ dry basis \\
Dry matter & 89.6 \\
Oil & 5.5 \\
Crude protein & 22.0 \\
Crude fibre & 3.3 \\
Ca & 2.0 \\
P & 1.0 \\
Mg & 0.2 \\
K & 0.8 \\
Na & 0.3 \\
Cl & 0.3 \\
\hline
\end{tabular}

( $\left.{ }^{*}\right)$ Supplies per kg: 7500 I.U. vit. A, 1480 I.U. vit. $D_{3}, 250 \mathrm{mg}$ vit. E, $25 \mathrm{mg}$ vit. $B_{1}, 150 \mathrm{mg}$ vit. $B_{2}, 45 \mathrm{mg}$ vit. $B_{6}, 55 \mathrm{mg}$ Ca-D-pantothenate, $550 \mathrm{mg}$ Niacin, $10 \mathrm{mg}$ Folic acid, $3525 \mathrm{mg}$ Choline chloride, $0.45 \mathrm{mg}$ Biotin, $0.01 \mathrm{mg}$ vit. $\mathrm{B}_{12}, 10 \mathrm{mg}$ vit. $\mathrm{K}_{3}, 550 \mathrm{mg}$ inositol, $25 \mathrm{mg}$ para-amino-benzoic acid, $75 \mathrm{mg}$ Etoxiquin.

$\left({ }^{\star *}\right)$ Supplies per kg: $172 \mathrm{mg} \mathrm{Fe,} 228 \mathrm{mg} \mathrm{Mn,} 200 \mathrm{mg} \mathrm{Zn,} 57.2 \mathrm{mg} \mathrm{Cu}$, $4.4 \mathrm{mg} \mathrm{Co,} 8 \mathrm{mg} \mathrm{I}$.

terminative Bacteriology 1974). The least detectable number of bacteria due to the method employed was about 1000 viable counts/gram gut contents.

Morphological investigations of gut mucus membranes

After removing samples for bacteriological investigations from each bird, eight one $\mathrm{cm}$ long pieces were cut at predetermined sites from the small intestine and caeca and fixed overnight in $2 \%$ formaldehyde, $2 \%$ glutaraldehyde in $0.1 \mathrm{M}$ sodium cacodylate buffer at $\mathrm{pH} 7.2$ with $2.5 \%$ sucrose, dehydrated and 
T a ble 2. Body weights, mortality rates and numbers of different bacteria in contents from the small intestine and caeca of willow ptarmigan chicks fed different diets.

\begin{tabular}{|c|c|c|c|c|c|c|c|c|c|}
\hline \multirow[t]{2}{*}{ Diet group } & \multirow{2}{*}{$\begin{array}{c}\text { Body weights } \\
7 \text { days after } \\
\text { hatching } \\
\text { (grams) } \\
\overline{\mathbf{x}} \pm \text { s.d. } \\
\end{array}$} & \multirow{2}{*}{\multicolumn{2}{|c|}{$\begin{array}{l}\text { Mortality } \\
\text { (Incidence) }\end{array}$}} & \multicolumn{6}{|c|}{$\begin{array}{c}\text { Small intestine } \\
\log _{10} \text { viable counts/g gut contents (ranges) }\end{array}$} \\
\hline & & & & $\begin{array}{l}\text { C. per- } \\
\text { fringens }\end{array}$ & $\begin{array}{l}\text { Entero- } \\
\text { cocci }\end{array}$ & $\begin{array}{l}\text { Coliform } \\
\text { bacteria }\end{array}$ & $\begin{array}{l}\text { Bacillus } \\
\text { sp. }\end{array}$ & $\begin{array}{c}\text { Propioni- } \\
\text { bacterium } \\
\text { sp. }\end{array}$ & $\begin{array}{r}\text { Lacto- } \\
\text { bacillu } \\
\text { sp. }\end{array}$ \\
\hline $\begin{array}{l}\text { Artificial } \\
\text { chick diet } \\
\text { (ACD) }\end{array}$ & $13.9 \pm 1.0$ & $6 / 10$ & 4 & $5.1-6.3$ & $8.0-10.6$ & $6.4-8.6$ & - & - & - \\
\hline $\begin{array}{l}\text { ACD plus } \\
\text { neomycin }\left({ }^{*}\right)\end{array}$ & & & & & & & & & \\
\hline $\begin{array}{l}0.01 \% \text { and } \\
\text { oxytetra- } \\
\text { cycline } \\
0.015 \% \text { in } \\
\text { the water }\end{array}$ & $22.3 \pm 2.5$ & $1 / 10$ & 6 & - & $5.1-6.5$ & - & $\begin{array}{c}3.8-5.9 \\
(2 / 6)\end{array}$ & $6.3-8.0$ & - \\
\hline $\begin{array}{l}\text { ACD supple- } \\
\text { mented with }\end{array}$ & & & & & & & & & \\
\hline $\begin{array}{l}0.2 \% \\
\text { ascorbic acid }\end{array}$ & $17.8 \pm 4.2$ & $2 / 10$ & 7 & $4.6-7.7$ & $6.1-8.6$ & - & $5.1-7.7$ & - & - \\
\hline $\begin{array}{l}\text { ACD supple- } \\
\text { mented with }\end{array}$ & & & & & & & & & \\
\hline $\begin{array}{l}0.2 \% \\
\text { ascorbic acid } \\
\text { and Vaccinium } \\
\text { myrtillus }\end{array}$ & $\begin{array}{l}31.7 \pm 4.0 \\
\mathrm{n}\end{array}$ & $0 / 10$ & 7 & 一 & $3.3-6.3$ & $3.0-4.0$ & 一 & - & $3.8-5$ \\
\hline
\end{tabular}

( $\left.{ }^{\star}\right)$ Neo-Terramycin vet. "Pfizer"

- Not detected (see "Materials and Methods")

embedded in Epon. Three micrometer sections were routinely stained with hematoxylin and eosin after removal of Epon by $3 \% \mathrm{KOH}$ in ethanol. In the microscope the gut wall of each sample was evaluated for bacteria colonizing the epithelium, villous epithelium erosion, and inflammatory cell reaction in the stratum propium.

Statistical testing of differences was done by the chi-square test (Sokal \& Rohlf 1973).

\section{Chick viability}

\section{RESULTS}

Chicks fed ACD only, showed high mortality rate (Table 2), and the cause of death was enteritis and diarrhoea. The four 
T a b l e 2. (Continued).

\begin{tabular}{|c|c|c|c|c|c|}
\hline \multicolumn{6}{|c|}{$\begin{array}{c}\text { Caeca } \\
\log _{10} \text { viable counts/g gut contents (ranges) }\end{array}$} \\
\hline $\begin{array}{l}\text { C. per- } \\
\text { fringens }\end{array}$ & $\begin{array}{l}\text { Entero- } \\
\text { cocci }\end{array}$ & $\begin{array}{c}\text { Coliform } \\
\text { bacteria }\end{array}$ & $\begin{array}{l}\text { Bacillus } \\
\text { sp. }\end{array}$ & $\begin{array}{l}\text { Propioni- } \\
\text { bacterium } \\
\text { sp. }\end{array}$ & $\begin{array}{c}\text { Lacto- } \\
\text { bacillus } \\
\text { sp. }\end{array}$ \\
\hline $6.0-10.0$ & $10.0-11.0$ & $7.8-10.8$ & - & - & - \\
\hline $\begin{array}{c}4.9-5.4 \\
(2 / 6)\end{array}$ & $6.7-9.8$ & 一 & $\begin{array}{l}7.6 \\
(1 / 6)\end{array}$ & $8.6-10.0$ & - \\
\hline $8.1-9.7$ & $8.7-9.8$ & - & $8.7-9.8$ & - & - \\
\hline 一 & $5.0-7.3$ & $6.3-8.0$ & - & - & $8.0-8.8$ \\
\hline
\end{tabular}

chicks that survived did not increase their body weight during the experiment.

The two groups fed ACD and either ascorbic acid supplement or antibiotics in the water showed low mortality rate. The cause of death was enteritis and diarrhoea. The weight gain for these two groups of chicks was significantly higher than for the former, but compared to the chicks that was given ACD supplemented with ascorbic acid and Vaccinium myrtillus, it was low.

\section{Bacteriological investigations}

There were high numbers of $\mathrm{C}$. perfringens, enterococci and coliforms in the gut contents of chicks that got ACD. Neomycin and oxytetracyclin in the water reduced the number of $\mathrm{C}$. per- 
fringens and coliforms significantly, and opened for establishment of a Bacillus sp. and Propionibacterium sp. A Veionella sp. was demonstrated in caecal contents of one chick from this group. Admixture of $0.2 \%$ ascorbic acid to the diet reduced the number of enterococci and especially coliforms, and opened for establishment of a Bacillus sp. In this group, Veionella sp., Clostridium sp., and Bacteroides sp. were isolated from caecal con-

Table 3. Percent of slides showing bacteria colonizing the epithelium and villous epithelium erosion in the small intestine and caeca of willow ptarmigan chicks fed different diets.

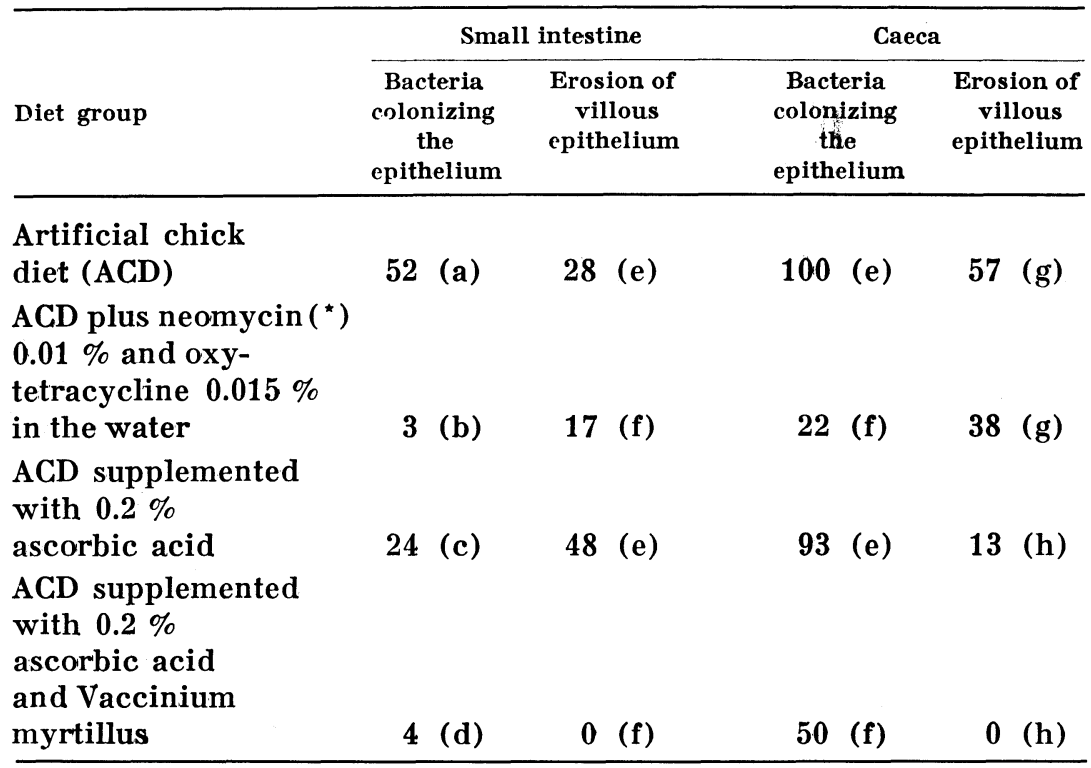

( ) Neo-Terramycin vet. "Pfizer".

In each column, the letters indicate significance of differences.

Due to small sample sizes and low incidences, several diet groups were combined in the statistical testing. In each column, the diet groups that were combined are marked with the same letter.

Groups marked $a$ and $b$ are significantly different at $P<0.005$.

Groups marked a and $d$ are significantly different at $P<0.005$.

Groups marked $b$ and $c$ are significantly different at $P<0.025$.

Groups marked a and $c$ are significantly different at $P<0.05$.

Groups marked $d$ and $c$ are significantly different at $P<0.05$.

Groups marked $b$ and $d$ are not significantly different.

Combined groups marked $e$ and $f$ are significantly different at $\mathrm{P}<0.005$.

Combined groups marked $g$ and $h$ are significantly different at $\mathrm{P}<0.01$ 
tents of three different chicks, respectively. Supplements of Vaccinium myrtillus reduced the number of $\mathrm{C}$. perfringens and enterococci, while the number of coliforms was higher in this group compared to those that got ascorbic acid supplement only. High numbers of a Lactobacillus sp. were demonstrated in gut contents from all chicks in this group. In all groups, the numbers of bacteria were higher in the caeca than in the small intestine.

\section{Morphological investigations}

Chicks fed ACD only, or ACD supplemented with ascorbic acid, showed higher incidences of bacteria colonizing the epithelium and of villous epithelium erosion than those that got either antibiotics in the water or ascorbic acid plus Vaccinium myrtillus supplement (Table 3 ). The inflammatory cell reaction was low in all groups.

\section{DISCUSSION}

Willow ptarmigan chicks that received ACD only, showed low body weight gain and high mortality rate. Overgrowth of gut bacteria (Table 2) and enteritis was the main reason for that. Young ptarmigan chicks need megadoses ascorbic acid in the diet for their bone development (Hanssen et al. 1979). The present study also demonstrated an inhibitory effect of ascorbic acid on coliforms in the gut. This is an interesting observation as coliform bacteria are common etiological agents in neonatal diarrhoea in many different animal species.

Nevertheless, chicks that were given antibiotics in the water tended to grow faster than chicks that got ascorbic acid supplement. The reason was probably that the antibiotics reduced the number of $\mathrm{C}$. perfringens in the gut (Table 2). The effect of dietary antibiotics on animal growth has been shown to be due to reduced numbers of C. perfringens (Sieburth et al. 1951) and enterococci (Sieburth et al. 1954). In the present study antibiotics also reduced the incidence of villous epithelium erosion and bacteria colonizing the epithelium (Table 3 ).

The far best performance was achieved by the group that received ACD supplemented with ascorbic acid and Vaccinium myrtillus plants. Vaccinium myrtillus supplements caused a further reduction in number of enterococci and growth of Lacto- 
bacillus sp. (Table 2). Introduction of Lactobacillus sp. into the gut is repeatedly shown to be beneficial to gut function (Sandine et al. 1972). The incidence of villous epithelium erosion and bacteria colonizing the epithelium was low in this group (Table 3 ).

Vaccinium myrtillus leaves contain organic acids and antimicrobial substances (Stangeland 1979), and in addition they bring bulk into the feed ration. This probably speed up the passage through the small intestine (Coombe \& Kay 1965), which may also have contributed (Dixon \& Paulley 1963) to the low number of bacteria in this gut region (Table 2).

\section{ACKNOWLEDGEMENTS}

We thank Drs. Einar Glausen and Jan Raa for valuable discussions and allowing us to use their facilities.

\section{REFERENCES}

Bergey's Manual of Determinative Bacteriology. 8th Ed. (Buchanan, E. E. \& N. E. Gibbons, eds.) The Williams \& Wilkins Company, Baltimore 1974.

Coombe, J. B. \& R. N. B. Kay: Passage of digesta through the intestines of the sheep. Retention times in the small and large intestines. Brit. J. Nutr. 1965, 19, 325-337.

Dixon, J. M. S. \& J. W. Paulley: Bacteriological and histological studies of the small intestine of rats treated with mecamylamine. Gut $1963,4,169-173$.

Hanssen, $I$. \& J. Ness: Chick nutrition and mortality in captive willow ptarmigan (Lagopus l. lagopus). Acta vet. scand. 1982, 23, 456465.

Hanssen, I., H. J. Grav, J. B. Steen \& H. Lysnes: Vitamin C deficiency in growing willow ptarmigan. J. Nutr. 1979, 109, $2260-2276$.

Hanssen, I., J. Ness \& J. B. Steen: Parental nutrition and chick production in captive willow ptarmigan (Lagopus l. lagopus). Acta vet. scand. $1982,23,528-538$.

Sandine, W. E., K. S. Muralidhara, P. R. Elliker \& D. C. England: Lactic acid bacteria in food and health: A review with special reference to enteropathogenic Escherichia coli as well as certain enteric diseases and their treatment with antibiotics and Lactobacilli. Milk Food Technol. 1972, 35, 691-702.

Sieburth, J. McN., J. Gutierrez, J. McGinnis, J. R. Stern \& B. H. Schneider: Effect of antibiotics on intestinal microflora and on growth of turkeys and pigs. Proc. Soc. exp. Biol. Med. 1951, 76, 15-18.

Sieburth, J. McN., J. J. Jezeski, E. G. Hill \& L. E. Carpenter: Some microbiological observations on the antibiotica-fed chick. Poultry Sci. 1954, 33, 753-762. 
Sokal, R. R. \& F. J. Rohlf: Introduction to Biostatistics. Chapter 13: Analysis of frequencies. W. H. Freeman and Company, San Francisco, 1973.

Stangeland, K.: Vannløselige organiske syrer og antimikrobielle stoffer i blader av Vaccinium myrtillus L. (Water soluble organic acids and antimicrobial substances in leaves from Vaccinium myrtilus L.). Cand. pharm. thesis, Institute of Pharmacy, University of Oslo, 1980.

\section{SAMMENDRAG}

Effekter av forskjellige dietter på overlevelse, og tarmmorfologi og -bakteriologi hos lirypekyllinger $i$ fangenskap.

Nylekte lirypekyllinger ble fôret med en kunstig diett (ACD) og tilskudd av forskjellig slag. En gruppe fikk askorbinsyre, en annen neomycin og oxytetracyclin i drikkevannet, og en tredje ble gitt tilskudd av askorbinsyre og nyutsprunget blåbærlyng.

Kyllingene som fikk bare ACD viste lav tilvekst og h $\varnothing y$ dødelighet. De hadde et høyt antall bakterier i tarmen, og frekvensen av tarmepitelerosjon og adherente bakterier til tarmepitelet var $\mathbf{h} \emptyset \mathbf{y}$.

Tilskudd av askorbinsyre til dietten reduserte antall koliforme bakterier i tarmen og $\varnothing \mathrm{kte}$ overlevelsesfrekvensen.

Tilsetning av antibiotika til drikkevannet reduserte antall C. perfringens, enterokokker og koliforme bakterier $\mathrm{i}$ tarmen og bedret forholdene i tarmepitelet.

Kyllingene som fikk tilskudd av både askorbinsyre og spirende blåbærlyng vokste raskt, alle overlevde og hadde et sunt tarmepitel. C. perfringens ble ikke påvist $\mathrm{i}$ tarmen hos disse kyllingene, og antall enterokokker og koliforme bakterier var dessuten lavt.

(Received January 20, 1984).

Reprints may be requested from: Ingolf Hanssen, Steinåsen 33, N-7000 Trondheim, Norway. 